\title{
Micropower system optimization for the telecommunication towers based on various renewable energy sources
}

\author{
Ahmed Abdulmula ${ }^{1}$, Kamaruzzaman Sopian ${ }^{1}$, Norasikin Ahmad Ludin ${ }^{1}$, Lim Chin Haw ${ }^{1}$, \\ Abdelnaser Elberki ${ }^{1}$, Fayez Aldawi ${ }^{2}$, Hazim Moria $^{2}$ \\ ${ }^{1}$ Solar Energy Research Institute (SERI), Universiti Kebangsaan Malaysia, Bangi, Malaysia \\ ${ }^{2}$ Department of Mechanical Engineering Technology Yanbu Industrial College, Yanbu Al-Sinaiyah, Kingdom of Saudi Arabia
}

\begin{tabular}{l} 
Article Info \\
\hline Article history: \\
Received Jun 22, 2020 \\
Revised Oct 25, 2021 \\
Accepted Nov 10, 2021 \\
\hline Keywords: \\
Green telecom tower \\
Hybrid micropower system \\
Renewable energy source \\
Solar photovoltaic technology \\
Supply-demand management
\end{tabular}

Corresponding Author:

Kamaruzzaman Sopian

Solar Energy Research Institute (SERI), Universiti Kebangsaan Malaysia

43600 Bangi, Selangor, Malaysia

Email: ksopian@ukm.edu.my

\begin{abstract}
This study investigates the technical and cost-effective performance of options renewable energy sources to develop a green off-grid telecommunication tower to replace diesel generators in Malaysia. For this purpose, the solar, wind, pico-hydro energy, along with diesel generators, were examined to compare. In addition, the modeling of hybrid powering systems was conducted using hybrid optimization model for energy (HOMER) simulation based on techno-economic analysis to determine the optimal economically feasible system. The optimization findings showed that the hybrid high-efficiency fixed photovoltaic (PV) system with battery followed by $2 \mathrm{~kW}$ pico-hydropower and battery are the optimal configurations for powering off-grid telecommunication towers in Malaysia with the lowest net present cost (NPC) and cost of energy (COE). These costs of NPC and COE are more down than diesel generator costs with battery by $17.45 \%, 16.45 \%, 15.9 \%$, and $15.5 \%$, respectively. Furthermore, the economic evaluation of the high-efficiency solar fixed PV panels system annual cash flow compared to the diesel generator with the battery system indicated a ten-year payback period.
\end{abstract}

This is an open access article under the $\underline{C C B Y-S A}$ license.

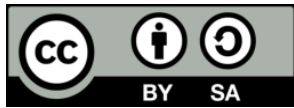

\section{INTRODUCTION}

In Malaysia, the mobile telecommunication industry is evolving rapidly to keep up with various applications and advanced technologies. As part of network system units, telecommunication towers (TTs) serve as terminal links between the subscribers and the backhaul network, which is the primary responsibility for network expansion. In order to improve and develop their services, cellular network operators in Malaysia build new TTs annually, which are, in some cases, off-grid sites in remote areas or on highways [1]. The TT consumes more than $57 \%$ of the remaining cellular network units [2]. Typically, an off-grid TT site is powering by a diesel generator (DG), which recently has become less favorable as a practical solution due to high operating costs and a harmful impact on the environment [3], [4]. Thus, providing a cost-effective power supply to reduce operational costs and environmental conservation of TTs operating is a critical challenge for cellular network operators to develop their network service. This has led cellular network operators to adopt renewable energy as alternative green solutions.

Powering off-grid TT sites with renewable energy is a great solution. It is clean, never inexhaustible, which can provide uninterrupted power. Because of the high operation cost and adverse impact on the environment, it has become necessary to replace diesel generators with green energy to operate off-grid 
telecommunication towers. Therefore, many previous literature references have discussed the power systems from renewable energy sources as a green and cost-effective solution to run off-grid telecommunication towers worldwide. Although Malaysia has many renewable energy sources such as hydro and wind energy resources, authors have focused on a solar energy source with different technologies to design power systems to run off-grid TT sites [5]-[9]. The present study compares various local renewable energy sources to develop the best cost-effective green micro-power system to operate off-grid TTs. The designed power system can power the TT all day with a minimum of energy waste. The simulation and optimization study are performed through technical-economic analysis using hybrid optimization model for energy (HOMER) Pro ${ }^{\circledR}$ software based on the lowest total net present cost (NPC), cost of energy (COE), and energy production. To the best of the authors' knowledge, a comprehensive comparison of various renewable energy with different technologies for powering TTs has never been performed in previous studies in Malaysia.

\section{RESEARCH METHOD}

The simulation and optimization of the hybrid power systems are performed by HOMER Pro® software based on techno-economic analysis. For calibration of the model and its validating data for the optimization and modeling, this research is based on dozens of high impact previously published papers in many from well-reputable scientific journals; that prove the HOMER software sufficiently accurate [10]-[12]. Data entry for simulation and optimization is conducted through the following: i) renewable energy sources for the site include temperature, wind speed, solar radiation, streamflow; ii) estimating the load profile of $\mathrm{tt}$; and iii) technical and financial parameters of selected hybrid system components modeling.

\subsection{The load profile assessment}

In order to estimate the energy load profile of TT, the present study adopts the power consumption modelling (PCM) method based on real-time data traffic load to maintaining a balance between the power supply and energy demand [13]. As reported in [13], the PCM method has achieved more energy-saving efficiency than the traditional approach, called the overall peak load method [14]-[17], which depends on estimating peak load all the time. As shown in Figure 1, the total daily energy load profile and the considered energy peak load are $27.29 \mathrm{kWh} /$ day and $1.233 \mathrm{~kW}$, respectively.

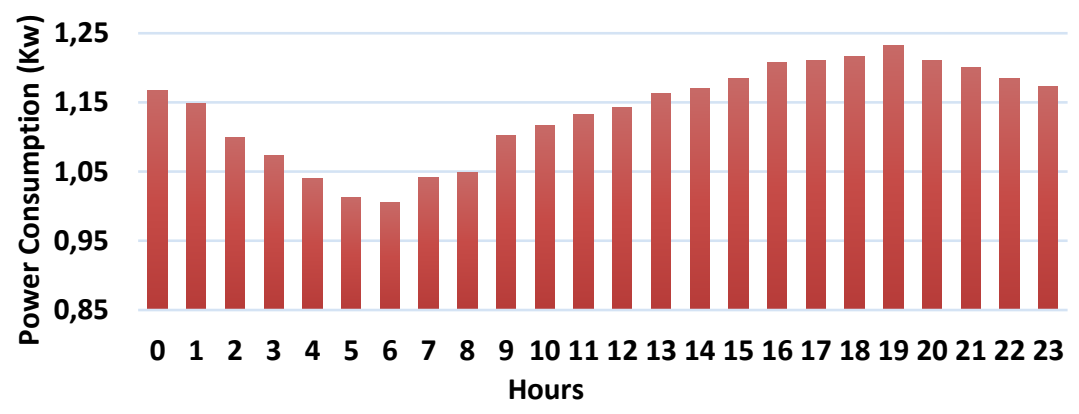

Figure 1. Daily energy load profile of TT under real-time data traffic load calculation

\subsection{Site description and renewable energy sources data collection}

Malaysia's potential renewable energy sources are considerable and varied [18]-[21]. Therefore, this study selected Kota Kinabalu, Sabah state, Malaysia $\left(5.9804^{\circ} \mathrm{N}, 116.0735^{\circ} \mathrm{E}\right)$ as a case study. As shown in Figure 2, Kota Kinabalu reflects Malaysia's general climatic condition and has a high potential for solar energy sources [22] and medium wind power. Besides, it has a considerable amount of annual seasonal rainfall that helped increase water flow and formed many streams and small rivers, which could be utilized as small-scale-hydropower [23]. Therefore, this chosen case study is very instructive to gain new knowledge and better insight into the research field. The data of solar radiation, wind speed, and temperature for the study location were obtained from the National Aeronautics and Space Administration (NASA) Surface Meteorology. Also, this study has considered the hydro streamflow source under monthly rainfall data in Sabah, State. As shown in Figure 2, the annual average of solar radiation is $5.12 \mathrm{kWh} / \mathrm{m}^{2} /$ day, with a high of $5.8 \mathrm{kWh} / \mathrm{m}^{2} /$ day in April and a low of $4.5 \mathrm{kWh} / \mathrm{m}^{2} /$ day in December. Figure 3 shows the monthly average wind speed, which reveals that the annual average wind speed is $3.24 \mathrm{~m} / \mathrm{s}$, with a low of $2.3 \mathrm{~m} / \mathrm{s}$ in May and a 
high of $4.82 \mathrm{~m} / \mathrm{s}$ in January. Figure 4 shows that the average yearly temperature is $25.17{ }^{\circ} \mathrm{C}$; It is from $24{ }^{\circ} \mathrm{C}$ in January and December to $26^{\circ} \mathrm{C}$ in April, August, and September. From Figure 5, it has been observed that the annual average streamflow of $170.0 \mathrm{~L} / \mathrm{s}$. This is due to heavy rain from the state of Sabah, which increases the speed of streamflow in rivers, especially during the northern monsoon period.

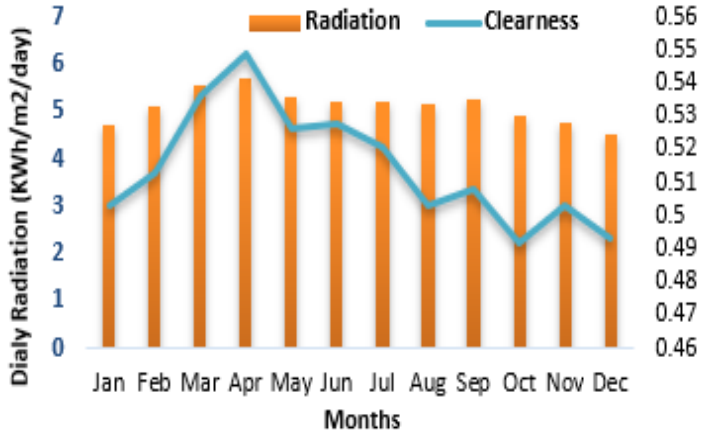

Figure 2. Global solar radiation and clearness index

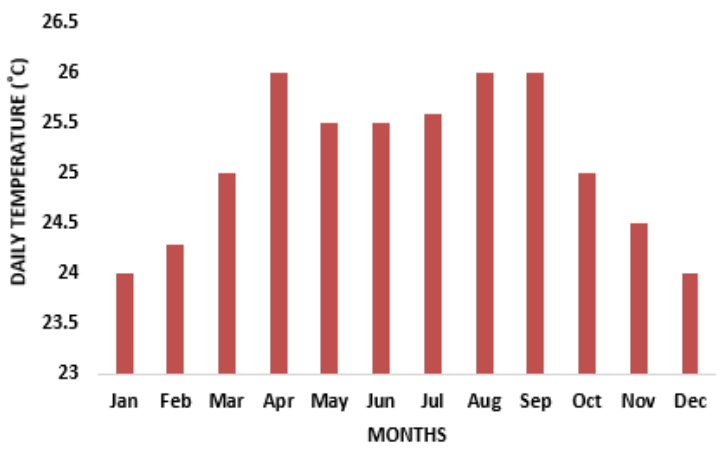

Figure 4. Daily temperature profile

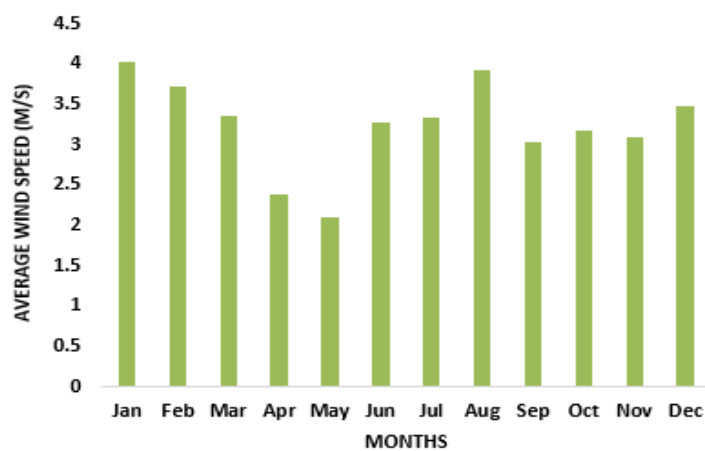

Figure 3. Monthly average wind speed

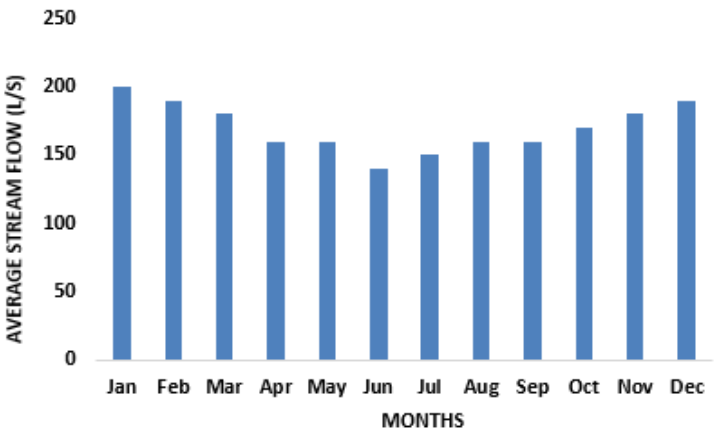

Figure 5. Streamflow profile

\subsection{Photovoltaic (PV) system modeling}

The power production PV system efficiency depends mainly on PV cell efficiency and the angle of PV panels installation. Typically, PV modules can install in two technologies way, fixed-tilt-mounted and using the axis-tracking technique. The present study proposed two solar PV systems for an investigation based on different tilt-angle installations with a maximum power point tracking (MPPT) controller, the PV fixed-tilt-mounted system, and the PV dual-axis tracker system. Moreover, to ensure proper performance, the PV system preferably comprises a high efficiency of the MPPT controller. The function of the MPPT is to control the charge of the battery effectively and support PV cells to produce the most considerable amount of energy [24]. Therefore, the two technologies hold potential for energy production with different economic costs. The study uses the high-efficiency SunPower, flat plate, X21-335W-BLK, 96 Monocrystalline Maxeon Gen III cells, with $\left(0.29 \% /{ }^{\circ} \mathrm{C}\right)$ Power Temperature Coefficient, which is suitable for the tropical regions. The technical and economic parameters inputs of the fixed PV and both types of PV tracking systems are described in detail in Table 1.

\subsection{Wind turbine modeling}

According to Figure 3, the average wind speed ranges from (1 to 6) $\mathrm{m} / \mathrm{s}$ during the year. Three different commercially horizontal-axis micro-wind turbines from AWS-HC Company have been considered to compare to select the most appropriate for the site. These small wind turbines for low wind speed could serve as the supplement source of the hybrid power system, especially with solar PV panels affected by clouds in the rainy months. The proposed wind turbines have a minimum start-up cut-in rate of $2.2 \mathrm{~m} / \mathrm{s}$ and the highest quality and efficiency with the $48 \mathrm{~V} \mathrm{DC}$ of wind controller. The output power of the turbines is $1800 \mathrm{~W}, 1500 \mathrm{~W}$, and $650 \mathrm{~W}$, respectively. Figure 6(a) shows the wind speed distribution of the site. The comparison was performed based on analyzing the power curve graph for each wind turbine through 
achieving the most considerable output power in the range of wind speed from 2 to $8 \mathrm{~m} / \mathrm{s}$. Figure 6(b) shows the power curve graphs for the three investigated small-wind turbines. The chart indicates the AWS-HC $1.8 \mathrm{~kW}$ has the highest performance than other turbines in a wind speed range of 2.2 to $8 \mathrm{~m} / \mathrm{s}$. According to the online wind turbine market pricing, the price of AWS-HC $1.8 \mathrm{~kW}$ is $\$ 4,000$. Accordingly, the capital, replacement, and operating and maintenance $(\mathrm{O} \& \mathrm{C})$ cost were estimated to be approximately $\$ 4,000, \$ 3,500$, and \$20.0/year, respectively.

Table 1. Details of the technical and financial parameters for three types of solar PV array systems

\begin{tabular}{ccc}
\hline Parameters & Fixed-tilt PV panel & Dual-axis tracker PV panel \\
\hline Tracking System & No tracking & Dual tracking \\
PV model size $(\mathrm{kW})$ & 0.335 & 0.335 \\
PV cell Efficiency & $21 \%$ & $21 \%$ \\
Derating Factor & $88 \%$ & $90 \%$ \\
Lifetime & 25 years & 25 years \\
Ground reflectance & $20 \%$ & $25 \%$ \\
Initial capital cost per 1 kW & $\$ 1500$ & $\$ 3000$ \\
Replacement cost per 1 kW & $\$ 1000$ & $\$ 2000$ \\
Operation \& Maintenance $($ O\&C) per 1 kW & $\$ 10 /$ year & $\$ 25 /$ year \\
Initial capital and Replacement cost per 1 kW for MPPT & $\$ 100$ & $\$ 100$ \\
\hline
\end{tabular}

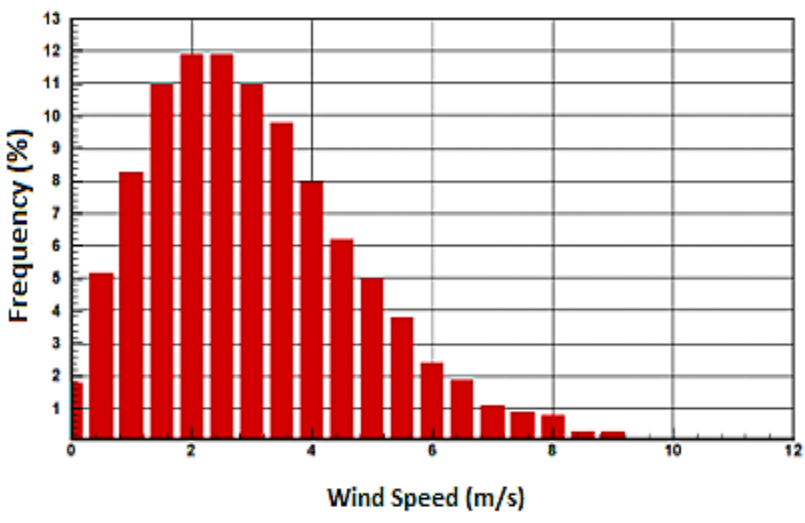

(a)

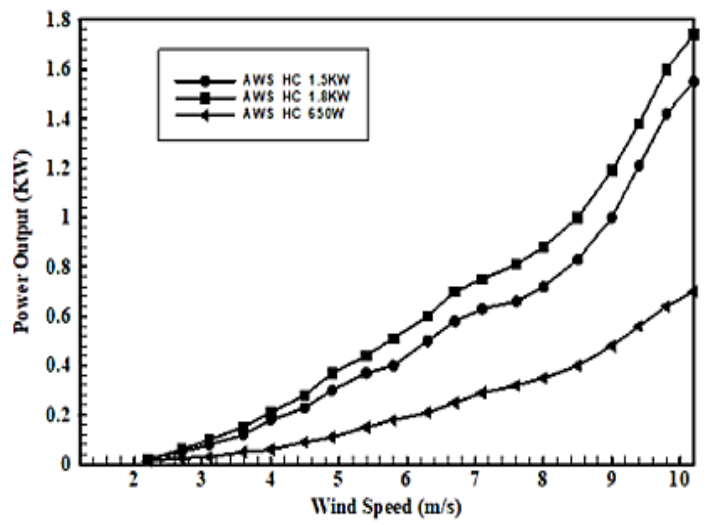

(b)

Figure 6. Wind turbine modeling: (a) the histogram of wind speed distribution and (b) power curve for the three types of small wind turbines

\subsection{Pico-hydropower modeling}

The design technology of hydroelectric varies by location and given river basin. The picohydropower is a minor type of hydroelectric power system that can generate electric power up to $5 \mathrm{~kW}$. According to the reference [24], pico-hydropower projects' total costs in remote locations are more than $\$ 5,000 / \mathrm{kW}$. The present study estimated that the cost is $\$ 6,000 / \mathrm{kW}$, including transportation, labor costs, and wiring connection costs. The electrical and mechanical equipment prices are estimated to comprise $50 \%$ or more of the total cost [25]. There is a range of technical parameters that have to take into account when choosing the appropriate type and size of the pico-hydropower turbine, which include the height of the flow of water called head $(\mathrm{H})$ and seasonal inflows of water, which called flow (Q) [26]. The higher the head and the faster the flow of water increases the amount of power generation. The capital cost, replacement cost, O\&C Cost, and Lifetime of the pico-hydro project are $\$ 12,000, \$ 6,000, \$ 1,200 / \mathrm{yr}$, and $25 \mathrm{yr}$, respectively. The details of hydro turbine parameters for the pico-hydropower system for simulation by HOMER Pro software are given in Table 2.

\subsection{Diesel generator modeling}

In order to guarantee power supply 24 hours, typically, the diesel generator is installed with a battery bank. Therefore, AC $1.5 \mathrm{~kW}$ fixed-capacity, silent DG with automatic transfer switch (ATS) are considered in the present study. According to the online high-quality diesel generator market, the average price of a $1.5 \mathrm{~kW}$ DG with ATS is between $\$ 330$ to $\$ 450$. The initial capital, replacement, and O\&C costs were estimated to be $\$ 400, \$ 400$, and $\$ 0.300$, respectively. It is important to note that a DG needs a car to carry the fuel to the site to run. Hence, the fuel price increase above the regular rate after adding 
transportation price. The diesel fuel price in Malaysia in 2020 is fixed at around $0.55 \$ / L$. So, by adding transportation prices, the cost of $0.96 \$ / \mathrm{L}$ is considered.

Table 2. Details of the hydro turbine characteristics

\begin{tabular}{cc}
\hline Parameters & Characteristics \\
\hline Available Head & $7.5 \mathrm{~m}$ \\
Design flow rate & $32 \mathrm{~L} / \mathrm{s}$ \\
Maximum flow ratio & $150 \%$ \\
Minimum flow ratio & $50 \%$ \\
Turbine efficiency & $85 \%$ \\
Nominal Capacity & $2 \mathrm{~kW}$ \\
Quantity Considered & 1 \\
Pipe head loss & $15 \%$ \\
Electrical Bus & DC \\
\hline
\end{tabular}

\subsection{Battery bank modeling}

In an off-grid connected hybrid renewable power system, sizing the batteries is calculated to cover the required load when there is no power production from renewable energy sources. Deep cycle batteries are usually used to handle regular charging and discharging, thus enhances usage for as long as possible. Trojan, SIND $4 \mathrm{~V} 1685 \mathrm{AH}$, high-quality deep-cycle flooded/advanced lead-acid batteries, and maintenance-free are selected in this study. The batteries included smart carbon technology as a standard feature to improve performance. The battery life is 17 years as IEC 61427 standards. The initial capital and the replacement cost of one battery are $\$ 800$ and $\$ 800$, respectively.

\subsection{Power converter modeling}

A system converter was added to maintain the flow of the generated AC power to the DC bus. The initial capital replacement costs were estimated at \$300. Lifetime and efficiency are 15 years and 95\%, respectively.

\section{RESULTS AND DISCUSSION}

Figure 7 presents the proposed architecture of the hybrid renewable power system combinations for simulation and optimization in HOMER Pro ${ }^{\circledR}$ software. The selected components of hybrid power systems have been determined at an economically acceptable cost under renewable sources' availability in a site and local weather conditions. The hybrid components chosen are: i) Diesel generator with battery (DG+b), ii) Fixed PV module with battery $(F P V+b)$, iii) Dual-Axis PV module tracker system with battery (DPV+b), iv) Fixed PV module and wind turbine with battery $(\mathrm{FPV}+\mathrm{WT}+\mathrm{b}), \mathrm{v})$ Dual-Axis PV module tracker and wind turbine with battery (DPV+WT+b), and vi) $2 \mathrm{KW}$ Pico-hydropower with battery $(\mathrm{HP}+\mathrm{b})$. According to the simulation/optimization results obtained from HOMER, the findings of the different configurations of the hybrid system are analyzed and compared.

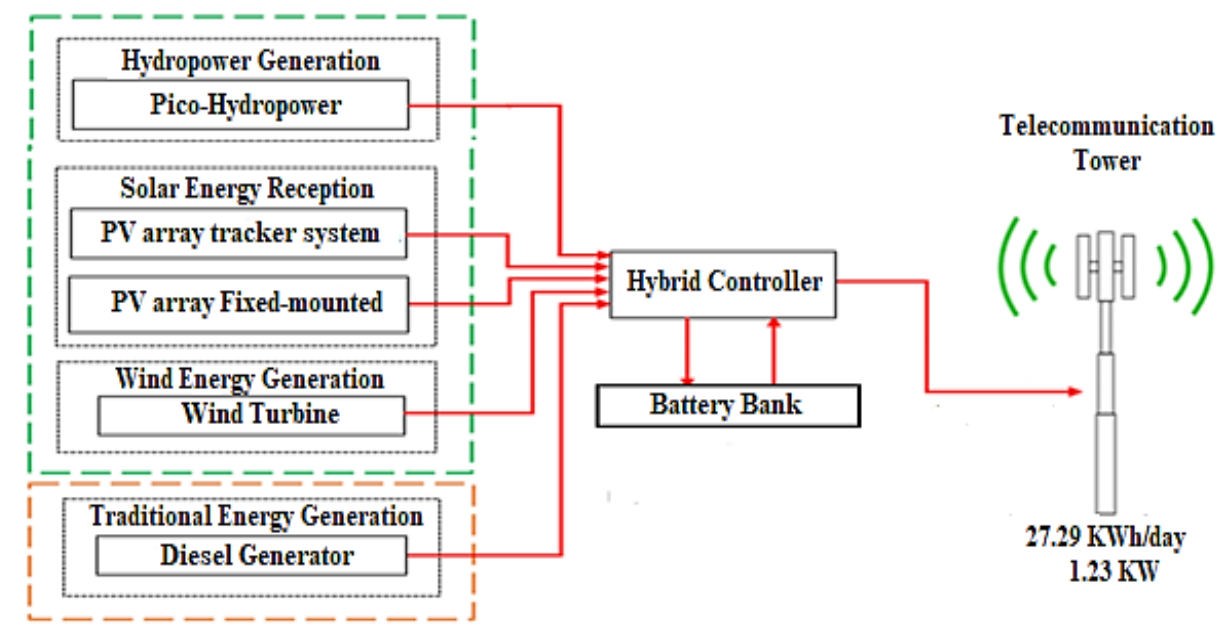

Figure 7. The overall architecture of hybrid power system combinations 


\subsection{Techno-economic simulation results and analysis}

The comparative techno-economic analysis results of the hybrid system are presented in Figure 8 and Table 3. The optimization result indicates that the fixed mounted PV and battery (FPV+b) comprises a $9 \mathrm{~kW}$ PV array, a $6 \mathrm{~kW}$ MPPT, and 17 batteries have the lowest both of NPC by $\$ 33,974$ and COE of $\$ 0.264 / \mathrm{kWh}$. The $2 \mathrm{~kW}$ pico-hydropower follows it with one battery of NPC by $\$ 34,590$ and a COE of $\$ 0.267 / \mathrm{kWh}$. These costs of NPC and COE of $(\mathrm{FPV}+\mathrm{b})$ and $(\mathrm{HP}+\mathrm{b})$ are lower than of diesel generator with battery (DG+b) by $17.45 \%, 16.45 \%, 15.9 \%$, and $15.5 \%$, respectively. The results also shown that, although the dual-axis PV tracking system (DPV+b) exerts a positive effect on reducing the size of the PV array by $33.33 \%$ compared to the size of the PV array $(F P V+b)$. However, due to the high initial cost of the technology and the increased maintenance costs of moving parts, its NPC and COE increased $12.48 \%$ and $12.58 \%$ compared with the fixed PV with battery $(\mathrm{FPV}+\mathrm{b})$.

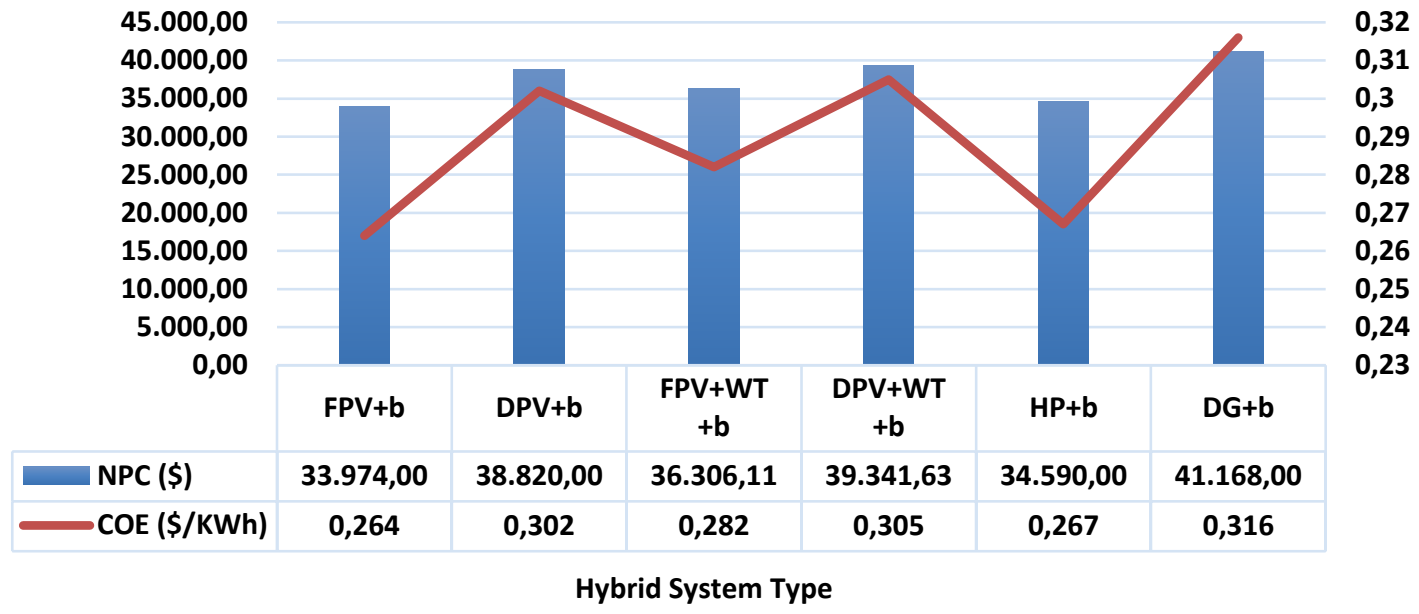

Figure 8. The Comparative results of NPC and COE

Table 3. Detailed comparative analysis results of hybrid system sizing

\begin{tabular}{cc}
\hline System Configurations & Sizing \\
\hline FPV+b & $9 \mathrm{~kW} \mathrm{PV/6} \mathrm{kW} \mathrm{MPPT+17} \mathrm{units}$ \\
DPV+b & $6 \mathrm{~kW} \mathrm{PV/6} \mathrm{kW} \mathrm{MPPT+24} \mathrm{units}$ \\
FPV+WT+b & $7 \mathrm{~kW} \mathrm{PV/6} \mathrm{kW} \mathrm{MPPT+1} \mathrm{unit+20} \mathrm{units}$ \\
DPV+WT+b & $6 \mathrm{~kW} \mathrm{PV/6} \mathrm{kW} \mathrm{MPPT+1unit+17} \mathrm{units}$ \\
HP+b & $2 \mathrm{~kW}+1$ unit \\
DG+b & $1.5 \mathrm{~kW}+1$ unit \\
\hline
\end{tabular}

Figure 9 presents the optimal system's annual cash flow compared to the traditional power generation system $(\mathrm{DG}+\mathrm{b})$ over 25 years to compare the cost-effectiveness of both systems. The initial cost of each $(\mathrm{FPV}+\mathrm{b})$ system is $\$ 32,200$. In contrast, the $(\mathrm{DG}+\mathrm{b})$ initial cost is lower and an estimated $\$ 2,776$. The operational cost indicator is steadily increasing in the life cycle until the end of the 25 years because of the high annual operating cost. The operating cost $(F P V+b)$ increases by a small amount until the end of 25 years by the difference of $\$ 14,891$. It is demonstrated that the investment in high-efficiency solar fixed PV panels technology contributes to a faster payback period by ten years, compared to usage DG with battery.

\subsection{Electricity production analysis}

The reliability of supplying power is also a critical criterion in designing autonomous hybrid renewable power systems. Figure 10 presents the yearly energy production of various hybrid system types. The simulation result shows that the DC primary load of TT is $9,955 \mathrm{kWh} /$ year. All hybrid system types fully meet TT's electric demand with some excess electricity production from the simulation findings. The optimal system comprised of fixed PV with a battery system $(\mathrm{FPV}+\mathrm{b})$ covers all the load demand for TTs of $12,642 \mathrm{kWh} /$ year, plus an electricity reserve of up to $2,687 \mathrm{kWh} /$ year at $21.25 \%$. This result indicates that the site has high solar energy that can generate electricity to TTs, with no power shortage throughout the year. Excess electricity is helpful because it can cover any potential increase in energy consumption. 


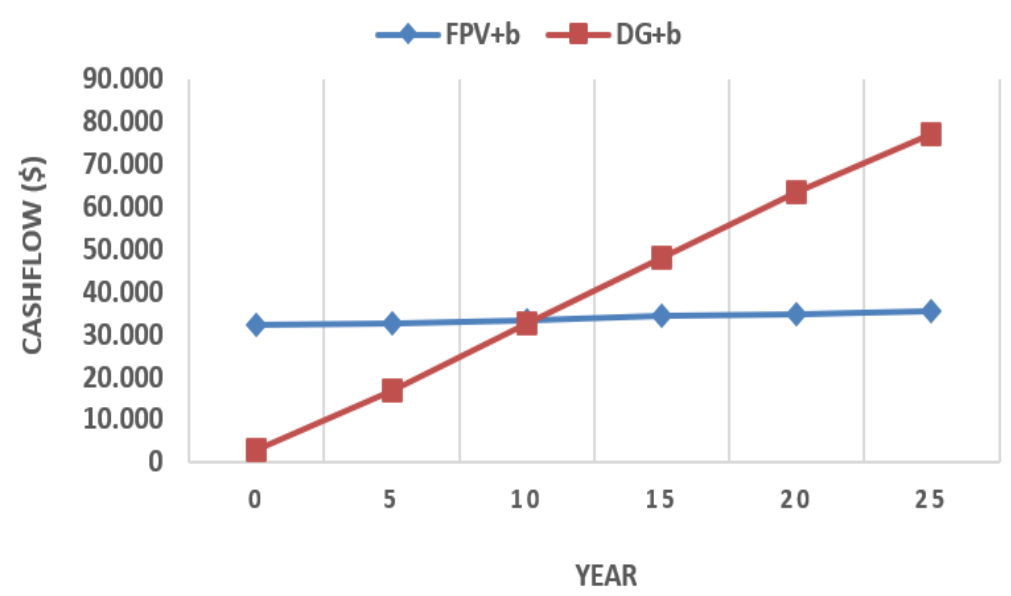

Figure 9. The life-cycle usage of FPV+b to DG/+b over the 25 years

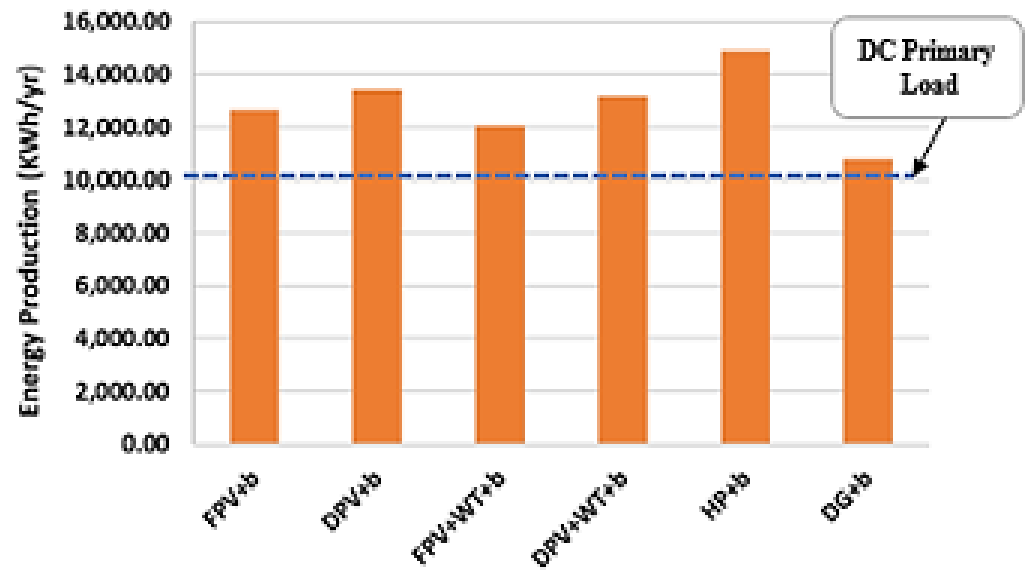

Hybrid System Type

Figure 10. Comparative result of yearly energy production

\section{CONCLUSION}

This investigation study aims to obtain the best cost-effective green micro-power system to operate off-grid TTs that replace diesel generators in a selected place in Malaysia. The proposed power system has been designed performed using the techno-economic analysis of HOMER simulation. Based on the obtained optimization results, the hybrid system comprising fixed-angle high-efficiency solar PV with the battery meets an off-grid telecommunication tower site's peak energy requirement with the lowest NPC and COE. A $2 \mathrm{~kW}$ pico-hydro follows it with a battery. These costs of NPC and COE are more down than diesel generator costs with battery by $17.45 \%, 16.45 \%, 15.9 \%$, and $15.5 \%$, respectively. The simple economic evaluation of the high-efficiency solar fixed PV panels system annual cash flow compared to the diesel generator with the battery system indicated a ten-year payback period. The study demonstrated that off-grid telecommunication towers are a promising field to apply solar energy technology in Malaysia and other countries with a similar climate to reduce operating costs and environmental conservation. This study's finding enriches body knowledge about generation clean power supply for off-grid telecommunication towers; thus, it can be used as a base to deploy green telecommunication towers in Malaysia.

\section{ACKNOWLEDGEMENTS}

The authors thank the associated personnel in any reference that contributed to this study; also, the authors would like to acknowledge the Solar Energy Research Institute (SERI) for providing technical assistance and financial support to this research paper through the grant (GUP-2018-127). 


\section{REFERENCES}

[1] J. Wu, Y. Zhang, M. Zukerman, and E. K.-N. Yung, "Energy-efficient base-stations sleep-mode techniques in green cellular networks: a survey," IEEE Communications Surveys \& Tutorials, vol. 17, no. 2, pp. 803-826, 2015, doi: 10.1109/COMST.2015.2403395.

[2] M. Alsharif, J. Kim, and J. Kim, "Green and sustainable cellular base stations: an overview and future research directions," Energies, vol. 10, no. 5, Apr. 2017, Art. no. 587, doi: 10.3390/en10050587.

[3] M. S. Okundamiya, J. O. Emagbetere, and E. A. Ogujor, "Assessment of renewable energy technology and a case of sustainable energy in mobile telecommunication sector,” The Scientific World Journal, vol. 2014, pp. 1-13, 2014, doi: 10.1155/2014/947281.

[4] J. Barzola, M. Espinoza, and F. Cabrera, "Analysis of hybrid solar/wind/diesel renewable energy system for off-grid rural electrification," International Journal of Renewable Energy Research, vol. 6, no. 3, pp. 1146-1152, 2016.

[5] M. S. M. Noor, Z. Adzis, Y. Z. Arief, and N. A. Muhamad, "Feasibility analysis of stand-alone renewable energy supply for telecommunication tower using Homer," Applied Mechanics and Materials, vol. 818, pp. 223-227, Jan. 2016, doi: 10.4028/www.scientific.net/AMM.818.223.

[6] M. H. Alsharif, R. Nordin, and M. Ismail, "Energy optimisation of hybrid off-grid system for remote telecommunication base station deployment in Malaysia," EURASIP Journal on Wireless Communications and Networking, vol. 2015, no. 1, Dec. 2015, Art. no. 64, doi: 10.1186/s13638-015-0284-7.

[7] A. Ghazali and A. M. Abdul Rahman, "The performance of three different solar panels for solar electricity applying solar tracking device under the malaysian climate condition," Energy and Environment Research, vol. 2, no. 1, May 2012, doi: 10.5539/eer.v2n1p235.

[8] A. Fazlizan, A. Abdulmula, A. N. Amran, C. H. Lim, and K. Sopian, "Performance evaluation of maximum light detection solar tracking system in the tropics," Journal of Mechanical Science and Technology, vol. 33, no. 3, pp. 1391-1397, Mar. 2019, doi: 10.1007/s12206-019-0240-2

[9] A. Fudholi, L. C. Haw, K. Sopian, and A. M. Omer Abdulmula, "Primary study of tracking photovoltaic system for mobile station in Malaysia," International Journal of Power Electronics and Drive Systems (IJPEDS), vol. 9, no. 1, Mar. 2018, Art. no. 427, doi: 10.11591/ijpeds.v9.i1.pp427-432.

[10] J. B. Fulzele and S. Dutt, "Optimium planning of hybrid renewable energy system using HOMER," International Journal of Electrical and Computer Engineering (IJECE), vol. 2, no. 1, Nov. 2011, doi: 10.11591/ijece.v2i1.157.

[11] S. Goyal, S. Mishra, and A. Bhatia, "A comparative approach between different optimize result in hybrid energy system using HOMER," International Journal of Electrical and Computer Engineering (IJECE), vol. 9, no. 1, Feb. 2019, Art. no. 141, doi: 10.11591/ijece.v9i1.pp141-147.

[12] M. N. Lakhoua, N. Walid, and C. Atef, "System analysis of a hybrid renewable energy system," International Journal of Electrical and Computer Engineering (IJECE), vol. 4, no. 3, Jun. 2014, doi: 10.11591/ijece.v4i3.5880.

[13] A. M. O. Abdulmula, K. Sopian, and L. C. Haw, "Power consumption modeling based on real-time data traffic for balancing power supply and energy demand to develop green telecommunication tower: a case study," Engineering, Technology \& Applied Science Research, vol. 9, no. 3, pp. 4159-4164, Jun. 2019, doi: 10.48084/etasr.2742.

[14] S. K. Khadka, J. N. Shrestha, and S. R. Shakya, "Comparative analysis of solar-wind hybrid system with diesel generator system in powering remote telecom towers of nepal using HOMER," in Proceedings of IOE Graduate Conference, 2014, pp. 438-445.

[15] A. Aris and B. Shabani, "Sustainable power supply solutions for off-grid base stations," Energies, vol. 8, no. 10, pp. 10904-10941, Sep. 2015, doi: 10.3390/en81010904.

[16] M. El Badawe, T. Iqbal, and G. K. Mann, "Optimization and a comparison between renewable and non-renewable energy systems for a telecommunication site," in 2012 25th IEEE Canadian Conference on Electrical and Computer Engineering (CCECE), Apr. 2012, pp. 1-5, doi: 10.1109/CCECE.2012.6335047.

[17] L. Olatomiwa, S. Mekhilef, A. S. N. Huda, and K. Sanusi, "Techno-economic analysis of hybrid PV-diesel-battery and PVwind-diesel-battery power systems for mobile BTS: the way forward for rural development," Energy Science \& Engineering, vol. 3, no. 4, pp. 271-285, Jul. 2015, doi: 10.1002/ese3.71.

[18] S. Tang, J. Chen, P. Sun, Y. Li, P. Yu, and E. Chen, "Current and future hydropower development in Southeast Asia countries (Malaysia, Indonesia, Thailand and Myanmar)," Energy Policy, vol. 129, pp. 239-249, Jun. 2019, doi: 10.1016/j.enpol.2019.02.036.

[19] M. Hossain et al., "A state-of-the-art review of hydropower in Malaysia as renewable energy: Current status and future prospects,” Energy Strategy Reviews, vol. 22, pp. 426-437, Nov. 2018, doi: 10.1016/j.esr.2018.11.001.

[20] A. Zaharim et al., "The impact of wind technology among rural community in Mersing Malaysia," in 2017 International Conference in Energy and Sustainability in Small Developing Economies (ES2DE), Jul. 2017, pp. 1-6, doi: 10.1109/ES2DE.2017.8015348.

[21] M. Z. Ibrahim, Y. K. Hwang, M. Ismail, and A. Albani, "Spatial analysis of wind potential for Malaysia," International Journal of Renewable Energy Research, vol. 5, no. 1, pp. 201-209, 2015.

[22] S. Mekhilef, A. Safari, W. E. S. Mustaffa, R. Saidur, R. Omar, and M. A. A. Younis, "Solar energy in Malaysia: Current state and prospects," Renewable and Sustainable Energy Reviews, vol. 16, no. 1, pp. 386-396, Jan. 2012, doi: 10.1016/j.rser.2011.08.003.

[23] T. S. Yee, S. Harun, K. B. Hee, and A. H. Fikri, "Evaluation of spatial and seasonal variations of dissolved organic matter in Maliau Basin, Sabah, Malaysia journal of tropical biology and conservation," Journal of Tropical Biology and Conservation, no. 14, pp. 105-124, 2017.

[24] M. A. Abdourraziq and M. Maaroufi, "Experimental verification of the main MPPT techniques for photovoltaic system," International Journal of Power Electronics and Drive Systems (IJPEDS), vol. 8, no. 1, Mar. 2017, Art. no. 384, doi: 10.11591/ijpeds.v8.i1.pp384-391.

[25] "Renewable Power Generation Costs in 2017," International Renewable Energy Agency, Feb. 2017. Accessed: Feb. 08, 2019. https://www.irena.org/publications/2018/Jan/Renewable-power-generation-costs-in-2017

[26] A. Kadier, M. S. Kalil, M. Pudukudy, H. A. Hasan, A. Mohamed, and A. A. Hamid, "Pico hydropower (PHP) development in Malaysia: Potential, present status, barriers and future perspectives," Renewable and Sustainable Energy Reviews, vol. 81, pp. 2796-2805, Jan. 2018, doi: 10.1016/j.rser.2017.06.084. 